\title{
PARADIGMS OF RURAL TOURISM IN SERBIA IN THE FUNCTION OF VILLAGE REVITALISATION
}

\author{
Jovo Medojevic*, Sasa Milosavljevic, Milan Punisic \\ Faculty of Sciences-Department of Geography, University of Pristina - temporarily settled in Kosovska Mitrovica, Serbia
}

\begin{abstract}
Rural regions in Serbia differ considerably in social, economic and demographic characteristics. Basic problems and trends almost all the rural regions share are migrations, poor diversification of economic activities, extensive agriculture, high level of unemployment, lack of employment possibilities, poor and underdeveloped infrastructure, low GDP per capita in comparison to the urban regions and unpolluted environment faced with potential threats . The subject of this paper is to point to the potentials of the rural tourism in Serbia with the aim of village revitalization, as well as its prevention from dying out. Also, the aim of the paper is to stress the fact that the rural tourism is a sustainable model of development and preservation of Serbian village and Serbian peasant from more aspects: economic, tourist, sociological, the spatial planning and ecological ones. Finally, the aim of the paper is to emphasize that it is possible to save village identity by its transformation into ethno village adopting the idea of European ethno villages. Rural tourism in Serbia must become 'main' industry' and a generator of sleeping national economy. The main benefits belong to the rural households. Tourist agencies must be engaged in enabling a dialogue between their employees and local representatives. Clients must not only be observers but also critics in the spirit of trust and transparency. A full and true comprehension of the rural tourism role is realized through revealing habits of the host, traditional values rooted in the existing culture, establishment of relations amongst population at the local level. Serbia has favourable conditions for developing rural tourism. It has, in the first place, preserved nature, mild climate, clean air, unpolluted rivers and lakes, rich flora and fauna. At the moment, 11 regional centres (comprising 10-15 municipal offices) are engaged in collecting and spreading relevant information for respective target groups, as well as in strengthening of activities in the local communities. Serbia earns about 10 billion dinnars annually from the rural tourism or one-sixth of gross home product. With a better utilization of the potentials, the participation could be much higher. Rural tourism offers great opportunity for new work posts, but capacities should be used to a greater extent and the problem of seasonality should also be overcome. All the key aims of the rural development in Serbia must be defined by the strategy: development of sustainable and efficient agricultural sector, standard of living of the population which lives from agriculture, creation of social and economic conditions in the rural regions, all of it within the National strategy of the rural development of the Republic of Serbia.
\end{abstract}

Key words: Republic of Serbia, Rural regions, Rural tourism, Village revitalization.

\section{Introduction}

According to the definition of the Organization of Economic Cooperation and Development (OECD) rural regions in Serbia cover up to $85 \%$ of the total territory (population density is below 150 inhabitants per $\mathrm{km2}$ ), in which lives more than a half of the total population of Serbia (55\%). Thus, 130 municipalities can be defined as rural and they comprise 3.904 settlements (Hopic, 2010). Rural regions in Serbia differ considerably in social, economic and demographic characteristics. Basic problems and trends almost all the rural regions share are

\footnotetext{
*Corresponding author:

Email: jovomedojevic@gmail.com
}

migrations, poor diversification of economic activities, extensive agriculture, high level of unemployment, lack of employment possibilities, poor and underdeveloped infrastructure, low GDP per capita in comparison to the urban regions and unpolluted environment faced with potential threats. At present, only Ministry of Agriculture, Forestry and Water Management (Republic of Serbia) i.e. Sector for rural development deals with the rural development.

At the moment, 11 regional centres (comprising 1015 municipal offices) are engaged in collecting and spreading relevant information for respective target groups, as well as in strengthening of activities in the local communities. One thing for certain is that the majority of natural resources with rich ecosystems 
and biodiversities, considerable human resources, economy activities and cultural heritage are concentrated in the rural regions of Republic of Serbia. In the last few years, big efforts have been made and assets invested into a strategy of rural areas preservation in the Republic of Serbia, where rural tourism stands out as a great motive potential and capacity.

To this end, the subject of this paper is to point to the potentials of the rural tourism in Serbia with the aim of village revitalization, as well as its prevention from dying out. Also, the aim of the paper is to stress the fact that the rural tourism is a sustainable model of development and preservation of Serbian village and Serbian peasant from more aspects: economic, tourist, sociological, the spatial planning and ecological ones. Finally, the aim of the paper is to emphasize that it is possible to save village identity by its transformation into ethno village adopting the idea of European ethno villages (Milosavljevic,2008).

\section{Methodology}

In our efforts to determine concrete and specific problems of the rural tourism in Serbia in the function of village revitalization, our methodological research has been based at three levels. The previous rural development in Serbia has been studied at the first level. At the second level, we have studied empirically contents and categorization of villages in Serbia for the rural tourism purposes: salases, ethno villages, ethno parks, have been studied at the second level. The third level deals with the benefits of the rural tourism at a micro-economic level (Darnil and Le Roux, 2005). These are, actually, parameters that directed our methodology of research towards the problem, subject and aim of the research. The first level of our study could be determined as macrosociology of tourism which studies social characteristics of tourism and tourist demand in rural tourism (Dan and Cohen, 1991). It means, that the rural tourism in Serbia was being observed as a social reality. We have considered influence of the rural tourism development from the economic aspect as well, through the prism of financial matter in the village, currency flow, savings and investments. The second and third level of our research deal with reality of the rural tourism development in Serbia.

These studies are based on the establishment of laws based on facts. At the same method used for submission: analogy, induction and deductive. During the data collection and processing and the fact we also use scientific methods of analysis and synthesis. Also, we have conducted research "In situ" for all the villages that are described in this paper.

\section{Analysis development of Serbian rural tourism}

Starting from the basic directions of world tourist trends, and the aims of long-term development of tourism in Serbia and the achieved level of its development, aspects of tourism in Serbia can be distinguished as follows: tourism of big cities, transitional tourism, spa tourism, the river Danube tourism, and tourism for special interests (Sevarlić 2006). Tourism concerning special interests comprises more aspects of tourism and is in demand showing a constant rise. It includes interest in culture, archeology, arts, architecture, sport, music, hobbies, hunting and fishing, farm stay and so on (Amirou, 200o). Based on the above mentioned interests a tourist product based on peoples' stay in villages has already been formed. Ecological elements should be included in the rural tourism development to its maximum; development of eco - village with various forms of healthy life such as healthy food, walking etc (Stankovic, 1994).

Serbia has favourable conditions for developing rural tourism. It has, in the first place, preserved nature, mild climate, clean air, unpolluted rivers and lakes, rich flora and fauna. These conveniences are especially noticeable in mountainous areas, on the slopes of Tara, Divcibare, Ozren, Povlen Bukulja, Rtanj, Oplenac and Suva Planina. Most of the villages are located in the vicinity of valuable cultural and historical monuments which can be visited by the tourists in organized tours. A considerable cultural value can be seen in buildings of traditional architecture, with characteristics of certain regions, as well as in the products of old crafts and handiwork, through which a rich cultural heritage of our nation can be represented. It is also possible to visit various exhibitions, especially those of naïve paintings, as well as tourist events and traditional shows which present our national customs and characteristics of rural life. This variety of tourist resources and diversity of cultural heritage is particularly enriched with noticeable hospitality and cordiality of the local people, who according to the tradition greet each tourist as a friend and offer a feast of healthy food based on natural products (Group of Authors, 1983).

Development of the rural tourism in Serbia, as an organized activity, began before more than a quarter of this century. Its very beginnings were connected with some spontaneous movements of the tourists, who wanted, even for a while, to run away from the city, an ecologically ruined environment, and spend some time in the countryside. In the beginning, only certain households were engaged in this type of tourism.

In time, this type of tourism being supported by the tourist associations gained mass character. With 
the aim of developing rural tourism in mountainous villages mainly, tourist associations were formed (Devici, Brankovina, Studenica), as well as tourist unions of municipalities (Kosjeric, Ivanjica, Knic). Agricultural cooperatives and catering and tourist industry got involved in this activity as well. According to the Tourist Unions' archive data, during 8o-ies of the last century, 50 villages with approximately 3.000 beds in 800 households were engaged in tourism.

\section{Research results}

On the basis of the data from the Tourist Organization of Serbia, an organized rural tourism is dealt with by the hosts in the municipalities such as follows: Knic,Raca,Gornji Milanovac, Sabac, Valjevo, Mionica, Ljig, Cacak, Lucani, Ivanjica, Pozega, Kosjeric, Uzice, Cajetina, Prijepolje, Kraljevo, Trstenik, Aleksandrovac, Brus, Soko Banja (Stankovic,1983).

Smells, sounds and tastes of the village are what make it special, more beautiful and pleasant than the city. From Vojvodina in the north, across Western, Central and Southern Serbia there are many differences in terms of details, but everywhere in Serbia the rhythm of village life is the rhythm of nature: the succession of seasons, transition from working day to the night of rest, natural order of things and people. In this survey, we shall present a division of Serbian villages which are to be engaged in the rural tourism as categorized by the Tourist Organization of Serbia. According to it, they can be divided into salases, ethno parks and eco-ethno villages (www.serbia.travel/destinations/villages/).

Salases: Having being deserted decades ago, and left to ruin, salases have come into revival becoming a very important element in Serbian tourism. In XIX and the beginning of XX century there was 1.000 of them. Today, more than 20 of them are restored for the tourist purposes and new ones appear constantly. They can be found in all of the three parts in Vojvodina: Backa, Banat and Srem. They used to be plain farms scattered across the fields, isolated from the rest of the world, far from the noise, pollution and haste of the modern world. Some salases are over 200 years old and are true ethno museums with a multitude of old objects, home furnishings and farming tools. They have built in furnaces and traditional guest rooms with large beds. In some salases Traditional way of Vojvodina life is kept, but many are arranged and arranged to suit modern needs, they have swimming pools, sport terrains, fish ponds, and other recreation forms. Larger salases have stud farms, small zoo and ethno museums or collections. They are ideal for a holiday with numerous recreation activities, but also for enjoying good Vojvodina cuisine, superb home wine and brandy, with merry sounds of tamburitza players (table 1).

Ethno parks are a result of conservation work on authentic samples of national architecture or purposeful modern way of construction in the recognizable ethno style of a certain geographic region. Differing from authentic Serbian villages, they are either completely tourist or cultural historical objects, i.e. local population does not live in them. They represent elaborately reconstructed ambience of the Serbian villages from one to two centuries ago, and are mostly built of wood and stone. Accommodation is in the rooms with village motifs and furniture, food is served in the ethno restaurants consisting of traditional dishes. Barns or similar objects of the old village households, together with carriages, cauldrons for brandy distillation, farming tools and other objects can be seen in the courtyards. Some of the ethno parks have wine cellars, stables with horses and museum ethno displays (table 2).

Eco-ethno villages: Serbian villages present real ecological paradise as seen with the eyes of a modern tourist from the city. In pleasant villages life is still rather idyllic and without stresses. In the countryside kept from all forms of pollution brought by modern civilization, with forests, pastures and plenty of greenery, people live peacefully, in mild climate, clean air and with healthy products. Village households in Serbia have always lived in harmony with nature and almost all the food products both of animal and plant origin are grown on their own farms. In real eco villages this is the case even today. Organic food, without genetic modifications and pesticides, which is specially appreciated in the world cuisine is something common, easily available, fresh and cheap in Serbian villages. Guests can pick their own unsprayed apples, wild strawberries and mushrooms, they can collect herbs, drink fresh milk, eat an egg or a soup made from chicken not bred in the dark of an industrial farm, but in the yard of a Serbian head of a household. All simple natural things everybody in the modern world needs are rare and expensive. Serbian village is also the most reliable guardian of the tradition. National crafts are kept through handicraft, embroidery and almost forgotten crafts such as weaving and woodcarving. Old customs are kept as well as authentic national music and polyphonic singing (table 3).

Festival of trumpeters in Guca presents a unique and a first-class show of national music, singing, dancing, customs, costumes and strongly propagates those kinds of art which are slowly sinking into oblivion. The program of this unique and really grandiose festival, which has reached unexpected heights and many people claim, with reason good 
Table 1. Salases in Vojvodina adapted for tourists ' needs

\begin{tabular}{|c|c|c|c|}
\hline Name of salas & $\begin{array}{c}\text { Distance from } \\
\text { Belgrade (in km) }\end{array}$ & Accommodation & Activities \\
\hline Cvetni i Majkin salas & 177 & $\begin{array}{c}15 \text { double rooms and three } \\
\text { bedded rooms }\end{array}$ & $\begin{array}{l}\text { riding school, carriage ride, } \\
\text { ethno workshops }\end{array}$ \\
\hline Rokin salas & 190 & $\begin{array}{c}\text { two four-bedded rooms and } 50 \\
\text { camping places }\end{array}$ & $\begin{array}{c}\text { organized campings, trips, } \\
\text { vocational lectures } \\
\end{array}$ \\
\hline Cvejin salas & 97 & three double rooms & $\begin{array}{c}\text { hunting, fishing, trips to Novi } \\
\text { Sad and Fruska Gora }\end{array}$ \\
\hline Salas 137 & 95 & three double rooms & $\begin{array}{l}\text { riding school, archery club, } \\
\text { carriage ride }\end{array}$ \\
\hline Salas 84 & 90 & two double rooms & fishing and hunting \\
\hline Nas salas & 95 & three bungalows & riding school \\
\hline Di da Hornjakov salas & 170 & $\begin{array}{l}\text { two double and one four- } \\
\text { bedded room }\end{array}$ & $\begin{array}{l}\text { ethno display, carriage ride, } \\
\text { sport activities }\end{array}$ \\
\hline Salas Bosnjak & 174 & $\begin{array}{l}\text { one single room, one double } \\
\text { room and one three bedded } \\
\text { room }\end{array}$ & $\begin{array}{l}\text { fishing, carriage ride, trips to } \\
\text { Sombor }\end{array}$ \\
\hline Salas Kraljica voca & 163 & three double suits & $\begin{array}{l}\text { activities in countryside (walks, } \\
\text { fishing, bird watching) }\end{array}$ \\
\hline Katai salas & 143 & a few rooms & $\begin{array}{c}\text { riding, nandcraft bakery } \\
\text { museum }\end{array}$ \\
\hline Perkov salas & 72 & a day visit only & $\begin{array}{l}\text { walking, collecting herbs, visit } \\
\text { to Fruska Gora monasteries }\end{array}$ \\
\hline
\end{tabular}

Source: Group of Authors, 2009

enough, that it is the largest one in the world. It is both original and spectacular. Special atmosphere and charm is gained by improvisation of the old Dragacevo wedding party, which presents very rich and interesting show of national folklore - national costumes, customs and dances of the region. Dragacevo wedding party makes an impression on all the visitors as it really is a curiosity itself - a rarity. Since 2004 an improvisation of the wedding party was replaced by a real wedding according to the old custom. The program of the Festival includes young men' competition in traditional sport - stone throwing from the shoulders, long jump, wrestling, shooting of the wedding apple. The first Festival of trumpeters in Guca was held in 1961, and the winner was Desimir Perisic from Goracic village. Thus, Guca became a capital of the trumpet. The entrance of Guca is guarded by a stone Monument to the trumpeter and in the centre there is a large Monument to the trumpeter. The climax of the Festival is the competition of trumpeters. The most spectacular are the beginning and the end of the competing, because all the participants take part in it. Accompanied with loud explosions of shotguns from the surrounding hills and the sounds of several hundred trumpets, the anthem of the Dragacevo festival 'From Ovcar and Kablar' echoes loudly through the whole of Dragacevo (Milosavljevic and Popovic, 2007). Trumpet pre-competitions are held in Kotraza, on Zlatibor mountain, Surdulica and Boljevac, so that all the parts of Serbia where the trumpet is played are equally represented in the competition for choosing the trumpeters for the final competition in Guca. A novelty has been introduced recently - a competition of young orchestra, where talented - future champions of golden -first trumpet can express their talents. During the Festival a variety of quality souvenirs - products of handicraft are sold. The most prominent place is taken up by the products of famous Dragacevo lady weavers from Donji Dubac, who exhibit their imaginative and always attractive creations. Dragacevo festival is an original and certainly a unique tourist event, which subsequently attracted admirers and participants from all the republics of former Yugoslavia. A great number of people from European and Non European countries heard of Guca festival, its good traditional music, fun and national food so that many of them began visiting it. A special hint of this event is achieved by an authentic space - a stage erected on the football pitch and nearby meadows, which allows numerous visitors to enjoy outstanding scenery of Dragacevo and relax both their bodies and souls. Guca offers possibilities of seeing numerous tourist 
Table 2. Ethno Parks in Serbia Made for Tourists

\begin{tabular}{|c|c|c|c|}
\hline $\begin{array}{l}\text { Name and location of } \\
\text { ethno park }\end{array}$ & $\begin{array}{c}\text { Distance from } \\
\text { Belgrade (in km) }\end{array}$ & Accommodation & Activities \\
\hline $\begin{array}{c}\text { Moravski konaci near } \\
\text { Velika Plana } \\
\end{array}$ & 89 & 9 suits with 21 bed & $\begin{array}{c}\text { walking, hunting, fishing swimming, } \\
\text { visits of Morava monasteries }\end{array}$ \\
\hline $\begin{array}{c}\text { Divljakovac on the } \\
\text { Bukulja mountain near } \\
\text { Arandjelovac }\end{array}$ & 80 & 18 beds in 5 vayat & recreation, long walks \\
\hline Trsic near Loznica & 140 & village household & $\begin{array}{l}\text { walking, farm work, visit to the } \\
\text { monasteries }\end{array}$ \\
\hline Kljuc raja near Mionica & 88 & $\begin{array}{l}\text { suits in the } \\
\text { restaurant attic }\end{array}$ & $\begin{array}{c}\text { visit to Vrujci spa, villages of Struganik } \\
\text { and Divcibare, Lelic and Celije } \\
\text { monasteries }\end{array}$ \\
\hline Vrhpolje near Ljubovija & 156 & 11 suits in vayat & $\begin{array}{l}\text { hunting, fishing, swimming, rafting, } \\
\text { Vulture watching }\end{array}$ \\
\hline $\begin{array}{c}\text { Zeleni cardaci near Tara } \\
\text { mountain }\end{array}$ & 190 & $\begin{array}{c}\text { Suits in 'Izvor, } \\
\text { 'Zubor' and 'Slavuj' }\end{array}$ & $\begin{array}{l}\text { walking, mountin, rafting on the Drina, } \\
\text { traveling by Sargan train }\end{array}$ \\
\hline $\begin{array}{c}\text { Raj ski konaci in village } \\
\text { Leusic near Gornji } \\
\text { Milanovac }\end{array}$ & 156 & $\begin{array}{l}4 \text { houses with } 21 \\
\text { bads }\end{array}$ & walking, fishing, Takovo area visit \\
\hline Gostoljublje near Kosjeric & 138 & 30 bads in vayat & $\begin{array}{c}\text { walking,running - track, swimming- } \\
\text { pool, waterfall }\end{array}$ \\
\hline $\begin{array}{l}\text { Vayat in village Gornja } \\
\text { Kravarica near Lucani }\end{array}$ & 170 & $\begin{array}{c}9 \text { double rooms and } \\
4 \text { suits }\end{array}$ & walking, hunting, rafting, Guca Festival \\
\hline $\begin{array}{c}\text { Sirogojno near Zlatibor } \\
\text { mountain }\end{array}$ & 220 & 29 bads in lodgins & $\begin{array}{c}\text { museum in the open, reconstruction of } \\
\text { the old customs, summer schools }\end{array}$ \\
\hline $\begin{array}{l}\text { Drvengrad (Custendorf) } \\
\text { near Tara mountain }\end{array}$ & 230 & $\begin{array}{c}9 \text { single, } 28 \text { double } \\
\text { and } 9 \text { three-bads } \\
\text { rooms }\end{array}$ & $\begin{array}{c}\text { walking, skiing, promotion of Kusturica } \\
\text { s films, Sargan } 8 \text { ride }\end{array}$ \\
\hline $\begin{array}{l}\text { Village Katici on Golija } \\
\text { mountain near Ivanjica }\end{array}$ & 215 & $\begin{array}{l}15 \text { double nad } \\
\text { three-bads rooms } \\
\text { and } 11 \text { suits }\end{array}$ & $\begin{array}{c}\text { walking, hunting, a little train for } \\
\text { mountain rounds, village jobs, old } \\
\text { crafts }\end{array}$ \\
\hline $\begin{array}{l}\text { Latkovac near } \\
\text { Aleksandrovac }\end{array}$ & 220 & $\begin{array}{c}5 \text { double, } 4 \text { three- } \\
\text { bads and one four- } \\
\text { bads room }\end{array}$ & $\begin{array}{c}\text { art workshops, walking, bicyclism, } \\
\text { Zupa picking }\end{array}$ \\
\hline Beli kamen near Prokuplje & 250 & $\begin{array}{l}8 \text { houses with } \\
\text { double rooms }\end{array}$ & $\begin{array}{c}\text { walking, fishing, swimming pool, sport } \\
\text { facilities }\end{array}$ \\
\hline $\begin{array}{l}\text { Archeo-ethno park in } \\
\text { village Ravna near } \\
\text { Knjazevac }\end{array}$ & 280 & & $\begin{array}{l}\text { an old school with the Roman steps and } \\
\text { wine museum }\end{array}$ \\
\hline $\begin{array}{c}\text { Torlaci in village Jakovac } \\
\text { near Knjazevac }\end{array}$ & 290 & $\begin{array}{l}3 \text { lodgins with } 30 \\
\text { bads }\end{array}$ & $\begin{array}{c}\text { village jobs, walking, hunting, fishing, } \\
\text { visiting Eastern Serbia }\end{array}$ \\
\hline $\begin{array}{l}\text { Rajac taverns in village } \\
\text { Rajac near Negotin }\end{array}$ & 256 & 4 double rooms & $\begin{array}{l}\text { ethnological object for making and } \\
\text { storing wine in traditional way }\end{array}$ \\
\hline
\end{tabular}

Source: Group of Authors, 2009 
Table 3. Municipalities and households engaged in rural tourism in Serbia

\begin{tabular}{|c|c|c|}
\hline Municipality & Village & Household \\
\hline Subotica & $\begin{array}{l}\text { Hajdukovo, Djurdjin, } \\
\text { Palic }\end{array}$ & numerous cardas and salases \\
\hline Senta & Backi breg & boarding house 'Kraljica voca' \\
\hline Backa Topóla & & Lovacki dom \\
\hline Sombor & Backi Monostor & household of 'Somodjvorac' \\
\hline Irig & & many salases \\
\hline Kovin & Skorenovac & households of Uzon, Korsos, Kovac and Ambrus \\
\hline Arandjelovac & Orasac & 'Karadjordjev vayat' \\
\hline Brus & Brzece, Ribari & $\begin{array}{l}\text { boarding house 'Dobrodolac' and 'Radigost', household of Zorica } \\
\text { Djordjevic }\end{array}$ \\
\hline $\begin{array}{l}\text { Gornji } \\
\text { Milanovac }\end{array}$ & $\begin{array}{l}\text { Bogdanica, Kostunici, } \\
\text { Gojna gora, Trudelj, } \\
\text { Rajac, Rudnik, Klaticevo, } \\
\text { Savinac }\end{array}$ & $\begin{array}{l}\text { households of Veselin Colovic, Stojka Obradovic, Bosa } \\
\text { Damnjanovic, Obrad Dmitrovic, Bosko Mijailovic, Radovan } \\
\text { Jovanovic, Stanislava Petrovic and Milic Pejkovic }\end{array}$ \\
\hline Knic & Bare, Zunje & $\begin{array}{l}\text { households of Dragana Arsenijevic, Mirjana Mirkovic, Gradimir } \\
\text { Obradovic, Simona Raspopovic, Vladan Jankovic, Bratislav } \\
\text { Markovic, Branislav Petrovic }\end{array}$ \\
\hline Lucani & $\begin{array}{l}\text { Kaona, Guca, Grab, } \\
\text { Milatovici }\end{array}$ & $\begin{array}{l}\text { households of Zdravko Davidovic, Predrag Radonjic, Miroslav } \\
\text { Koricanac, Momcilo Knezevic, Ratko Lazovic, Bozanic, Zoran } \\
\text { Jovicic and Milorad Ruzic }\end{array}$ \\
\hline Topóla & Lipovac & household of Marija Ristovic \\
\hline Valjevo & $\begin{array}{l}\text { Brankovina, Popucke, } \\
\text { Suvodonje, Valjevska } \\
\text { Kamenica }\end{array}$ & $\begin{array}{l}\text { Households of Jelica Todorovic, Jovanovic, Dragutin Zivanic and } \\
\text { Branko Rakic }\end{array}$ \\
\hline Kosjeric & $\begin{array}{l}\text { Seca reka, Mionica, Donji } \\
\text { taor, Skakavci }\end{array}$ & $\begin{array}{l}\text { households of Radomir Ignjatovic, Milutin Jovanovic, Mileta } \\
\text { Lukovic, Milovan Pantovic, Radisa Milovanovic, Jagoda } \\
\text { Marinkovic, Mihajlo Joksimovic, Mika Milojevic, Radivoj Trnavac } \\
\end{array}$ \\
\hline Ljig & Slavkovica, Belanovica & $\begin{array}{l}\text { will 'kod uce', households of Nenad Nikolic, Dragoslav } \\
\text { Desivojevic, Milijan Milosevic and Rade Tomic }\end{array}$ \\
\hline Pozega & SrednjaDobrinja & households of Milan Kovacevic and Tomislav Kovacevic \\
\hline Uzice & $\begin{array}{l}\text { Kremna, Potpec, Mokra } \\
\text { gora }\end{array}$ & $\begin{array}{l}\text { households of Ruza Ivanovic, Stjepan Stamenic, Stevan Tomic, } \\
\text { Ratomirka Jovanovic, Milos Guskic and Slavenka Stojic }\end{array}$ \\
\hline Cacak & Prislonica & household of Misa Nikodin \\
\hline Cajetina & Rozanstvo, Sirogojno & households of Dragan Melovic and Dobrivoje Milic \\
\hline Zajecar & Mali Izvor & household of 'zeleni zee' \\
\hline Knjazevac & $\begin{array}{l}\text { Râvna, Janja, Novo } \\
\text { korito, Crni vrh, } \\
\text { Grădişte, Balta-Berilovac }\end{array}$ & $\begin{array}{l}\text { households of Bratislava Radisavljevic, Ljiljana Zivkovic, Zoran } \\
\text { Milijic, Brana Veljkovic and Ivan Puletic }\end{array}$ \\
\hline Donji Milanovac & Krapacos & kapetan Misin breg and gallery 'Covek drvo i voda' \\
\hline Negotin & Rajac, Rogljevo, Tamnic & $\begin{array}{l}\text { households of Miroslav Karamancic, Gradimir Stankovic, } \\
\text { Ljubivoje Radosavljevic, Sasa Milic, Radoslav Zikic, Segan, } \\
\text { Dragoslav Radunovic and Miroslav Tanic }\end{array}$ \\
\hline Soko Banja & Josanica, Trubarevac & households of Danijela Lazic, Slobodan Jeftic and Lei a Stankovic \\
\hline Ivanjica & Lisa, Katici, Marina reka & $\begin{array}{l}\text { boarding house Milicevic and Obradovic and households of Ilija } \\
\text { Milicevic and Marinkovic }\end{array}$ \\
\hline Kraljevo & Lopatnica & household of Milosevic \\
\hline Prijepolje & $\begin{array}{l}\text { Sopotnica, Kamena Gora, } \\
\text { Jabuka, Gostun }\end{array}$ & \\
\hline Trstenik & Brezovica & boarding house 'Brezovica' \\
\hline Bujanovac & Jablanica & households of Nenad Mitic and Andon Dimitrijevic \\
\hline
\end{tabular}

Source: www.serbia.travel/destinations/villages 
attractions and sightseeing of 'Small Switzerland' as people call Dragacevo (Popovic, 2007). Organizers have introduced an international competition for the First trumpet of the world as well as an academy for trumpet in order to make this event even more known to the world.

Sargan pass, named after snake sarka, stands as a threshold between Tara and Zlatibor mountains. This, a thousand metres high pass is the place where thick conifer forests of Tara become sparse and spacious meadows of Zlatibor with individual groups of pines start spreading. The pass has always been a difficult obstacle on the road from Bosnia to Serbia via Visegrad and Uzice. Under Sargan there is a settlement Mokra Gora. It was named after many springs of curable water which effects can be regarded as miraculous. There is also the Kamisa river which runs from Vijogor similar to Sargan railway. It forms an unusually beautiful waterfall about twenty metres high - Veliki Skakavac. Houses in Mokra Gora have preserved the original look from the time when the first train whistled on the slopes of Sargan. Sargan railway of narrow platform, $760 \mathrm{~mm}$ of width, began to work on 25 January in 1925. After that, during 49 years and 25 days a train called 'Cira' from Uzice over Sargan to Visegrad and the seaside. Due to the estimation of not being profitable enough, the railway was closed on 28 February 1974 Sargan railway is a unique piece of construction by which a height difference of $300 \mathrm{~m}$ along $15.440 \mathrm{~m}$, and 22 tunnels, 5 bridges and mountain passage was overcome. It was named 'eight' because the railway shape between Mokra Gora valley and Sargan pass resembles number eight. Today, Sargan 8-shaped railway is rebuilt and used solely for tourist purposes. The starting station is in Mokra Gora. On the slope above the station in Mecavnik, our famous film director Emir Kusturica has built an ethno village 'Drvengrad' (Kustendorf), where the shooting of his film 'Life is a miracle' took place. Two kilometers far from it, the railway slowly goes up the pass. If one uses a short cut he can get to Jatare station in a few minutes while the train needs to cover quite a number of kilometres along Kamisa river to get there. In the near vicinity of Jatare station there is a Golubic station, which was built by Emir Kusturica for his film needs. In order to overcome this climb the train starts making a shape of double eight going through the tunnels and bridges. Passengers used to cross that part on foot in the past as it was faster. It represents the most interesting part of the trip today because no one knows which side of the world he is on after the third tunnel. The last tunnel through which the train runs is Alexander's tunnel, $1.666 \mathrm{~m}$ long and differently from others is straight. Alexander 's tunnel ends on Sargan pass at Sargan-Vitasi station. It is, at present, the last stop of the trip. Plans have been made for the Sargan railway to be connected to the Bar railway in Zlatibor, and also for the rails on the other side to Visegrad to be built. The area of Gruza is the most pleasant part of Sumadija (Stankovic, 2001). A river of Gruza was tamed and transformed into a large lake. On the north of the lake, towards the heights of Rudnik and Jesevica, sharp peaks appear above the valley, which cannot be seen anywhere, not even in the Prokletije. These cliffs are, together with neighbouring Ostrovica a geological souvenir of the past volcano activities of mountains rich with ore. There is a belief that Gruza used to be a much larger lake and that the sharp cliffs were used for the boats to be tied to. The remains of the city built by despot Stefan Lazarevic can still be found on the sharp cliffs. A town of Borac was overtaken by the Hungarians while the Turks burnt it down. Under the cliffs in thick coppice woods a church, that is by a legend connected with emperor Dusan's sister and Vukasin Mrnjavcevic's mother, has been preserved.

The surrounding of Boracki krs was a favourite hunting site of emperor Dusan. Hunters have gathered together in Gruza up to this day. In the second week of February Borac is a host to the hunters from all over Serbia. Traditional fox chase is a famous hunting event of this area. Guests do not visit Borac just for hunting though. Large lake is ideal for rowing. When autumn arrives and autumn colours make Boracki krs even more colorful, painters come to the traditional 'Gruza autumn'. Apart from rocky cliffs numerous mills are also a common motif for the painters. On Rudnik Mountain there are monasteries of Vracevsnica, Voljavca, Ramaca and Vujan. In Gornje Crnuce there is a house of Milos Obrenovic, where can still be found the remains of Rudnik and Ostrovica towns on the heights. On the eastern side of Gruza there are Gledic mountains with two most beautiful monasteries of Morava school Ljubostinja and Kalenic. Monasteris Sarinac, Raletinac and Denkovac were named after three sisters who built them. In the area of Gruza there are many cult trunks - notes. Along the valley of Gruza runs a famous 'Danish royal train' a name created by play on words of 'daily train to Kraljevo'.

During all these years rural tourism in Serbia has been neglected. There is more thought, talk and investing in a campaign of rural products and rural tourism in Serbia nowadays, though. Tourist organizations understand that the rural tourism income is very good and that rural tourism develops as a very important part of economy. Much more attention is being paid to the environment and culture protection in the village as well.

However, education concerning rural tourism development is very poor. Rural tourism is a reality and presents strong motive potential for the economic development of Serbia. Social, cultural and 
financial benefits from the village activities are recognizable. They are not locally equal and evenly distributed among the domicile population though. In the rural tourism offer there is no clearly differentiated information on quality of tourist stay. Sometimes, when you look at some tourist offers you have an impression that 'selling a dream' is on, everything looks attractive, exiting, interesting, colorful at the sight, but in reality, it is not quite so. We have observed that some individuals have a short term interest for a quick profit. It certainly does not correspond with just and good perspective.

\section{Discussion}

Today, in the rural regions of the Republic of Serbia there are 32,00o beds - both registered and unregistered ones, 10,00o of which are beds in the rural households (www.serbia.travel/destinations/villages/). Rural tourism is particularly developed in Central Serbia and Vojvodina, and all master plans for tourist destinations are focused on the development of the rural environment, such as Stara Planina, Gornje i Donje Podunavlje. Such development includes cultural resources and spas because Serbia has a great unused natural and cultural wealth and great potential for such a development (Cvetković, 2007).

Serbia earns about 10 billion dinnars annually from the rural tourism or one-sixth of gross home product. With a better utilization of the potentials, the participation could be much higher. Rural tourism offers great opportunity for new work posts, but capacities should be used to a greater extent and the problem of seasonality should also be overcome (Unkovic, 2001).

Trend of the tourism development in the world is the rural tourism, partially because narrow sea shores are already overcrowded by the tourists during bathing seasons and the number of tourists in the world is increasing. The World Tourist Organization (WTO) predicts that in 2020, there will be 1.6 billion foreign tourists in the world, which is $100 \%$ more than in 2006. WTO experts, who visited Serbia several years ago, on the basis of determined potentials recommended to Serbia to start developing rural

tourism

(www.turizam.merr.gov.rs/images/stories/MDGIF/Na tional\%2oworkshop_Serbian.pdf).

Ministry of Economy of the Republic of Serbia has produced a Strategy for the rural tourism development. The strategy treats rural tourism as a priority, emphasizing specially the development of eco-tourist villages in the mountainous area - that offer healthy environment, ecological food, agreeable surroundings, active holiday in the countryside, ethnographic and other cultural and historical values. In the development of the mountain villages so far, a dominant and often the only earning activity has been agriculture (mainly farming and cattle raising). Other numerous activities of the domicile population based on various and valuable natural and anthropogenic local resources were mainly left on the margins of events. So was the tourist activity which is an important factor of the future development of these villages in Serbia.

It is foreseen by the master plan that the tourist development should be focused on the 12 priority clusters such as follows: Golija, Zlatibor and Zlatar, Kopaonik, Fruska Gora, Central Serbia, Gornje Podunavlje, Donje Podunavlje, Eastern Serbia, Northern Serbia, Southern Banat, Soko Banja and South-East Serbia (www.selo.rs/Master-plan-razvojaseoskog-turizma-Srbije_516).

Most citizens of Serbia make holiday plans for the seaside, which means abroad, while the rural tourism is interesting mainly for those with a lower standard of living. The very holiday in the village is a need for all people who live in cities, including citizens of Serbia. The fact that a certain number of people does not have possibilities for traveling at all, while the others have relatives living in villages, where they can spend weekends or holidays. All of those who decide to spend holidays in the village have numerous possibilities for an active holiday. Only some of them will be mentioned here. Walking is an activity anybody can go in for, including very old people. However, for those who are strong, and more fit there is an unlimited number of possibilities for an active holiday. Lovers of fishing can fish where it is convenient and can spend days by the water, making bonfires or just enjoying company of other people in the open. Horse riders can enjoy themselves riding in beautiful scenery and spend several days in riding around with a help of their host, visiting villages and village households. Hunters can go hunting together with their hosts, or from time to time along with other activities or on the daily basis. Many foreigners are interested in the way of life of other nations, in this case the Serbs, and it would be interesting for them to visit old craftsmen, naïve painters, local fairs, wedding-parties, evening gatherings, harvests, folk shows. Lovers of history have many possibilities to visit old churches, monasteries or archeological sites in nearby or far surroundings. Let us mention some of them: Milesevo, Studenica, Zica, Ljubostinja, monasteries of Ovcar-Kablar gorge, Fruska Gora monasteries, Sirmium, Lepenski Vir, Gamzigrad, Romuliana, Skull Tower. Lovers of winter sports can stay in our mountains enjoying winter idyllic scenery and sports. Ornithologists have possibilities for bird watching. People with minor health problems can start getting cured or try to lose excessive weight. 
Painters and sculptors, professionals or amateurs alike can organize colonies and get inspired by the countryside and the environment in general. Lovers of rafting can enjoy the adventures on the rivers of Serbia. Mountaineers can climb the mountains, bicyclists can ride bikes, biologists can collect the herbs and fungi. Apart from this, tourists can play soccer, basketball, handball, tennis, swim in the swimming pools, visit café bars, restaurants and discotheques. The main activity for a number of people who decide to spend holidays in Serbia should be daily farming activities in the very village household or its close vicinity. In addition to the above mentioned, there is a number of attractive village jobs such as fruit picking, brandy distilling, grass mowing, corn grinding, fruit grafting, haystack making and watering vegetables, working with domestic animals, knitting, embroidery, preparing pickles etc.

Our research has shown that there is no balance in the supply and demand for rural village services (Young,1973). There is no balance of catering activities suggested by tourist operators and the hosts, domicile population or, at least, some of them. The former ones take part in an important way in determining these activities with a possibility to modify, reverse, and stop or run as modelers. A connection between travelers (clients) and their hosts must be allowed at a personal, cultural and economic level. Economic resources and financial effects should be evenly distributed among the domicile population thus giving contribution to the sustainable development of their region.

\section{Conclusion}

Taking into account progressive development of the ethno village in Europe, it is evident that the ethno village can be regarded as a model of village ambience preservation. Preservation and transition of Serbian village are both necessary and inevitable. However, in our opinion, a village in Serbia must not be given a character of a preserved village with preserved tradition and culture only. Character of rural tourism development in Serbia must have a tendency of keeping villages alive. Serbian village must be sustainable. Rural tourism should be seen as a financial support in the function of the village survival, for the interest in living in a village is reduced or to be more precise - it does not exist at all. It would also be useful to brand and promote individuality of each village such as Guca, Mokra Gora. Also, Serbian village as a rural community cannot survive as a model of rural tourism. Serbian village can survive only if it is supported by agriculture. That is why it is necessary, primarily, to have a strategic plan of sustainable development made for each village, with all the important aims of the rural development defined. All the key aims of the rural development in Serbia must be defined by the strategy: development of sustainable and efficient agricultural sector, standard of living of the population which lives from agriculture, creation of social and economic conditions in the rural regions, all of it within the National strategy of the rural development of the Republic of Serbia.

Owing to numerous positive trends of development, tourist activities have been classified amongst the most dynamic and propulsive part of economy, with many multiplicative effects. (in the period of 1990 - 2011). Thus, a strong generating function in a wide range of activities is being given to the tourism, which is being included within the priorities of economy development of the Republic of Serbia. Strategy of tourism development in Serbia determines selective approach, where rural tourism is treated as a priority in regard to the other types of tourism related to special interests. Development of eco-tourist villages in the mountainous areas that offer healthy environment, eco food, pleasant ambience, active rest in the countryside, ethnographic and other cultural and historical values. Rural tourism development in Serbia in the function of village revitalization enables rural population to gain certain benefits at the micro-economic level such as follows:

\section{- Starting economic activities of the region \\ - Additional financing of rural households \\ - Creation of personal and cultural exchanges among the population \\ - Motivating population for the aim of shared activities and projects \\ - Rising of population enthusiasm for taking part in beneficial activities concerning all.}

A return to the village (return to the rural fire) is also expected, at the demographic level i.e. marriages and childbirths that would lead to the rise of village population. All of these plans are achievable. Rural tourism in Serbia must become 'main' industry' and a generator of sleeping national economy. The main benefits belong to the rural households. However, we expect rural tourism needs to be clarified by establishing and forcing basic criteria for a strong tourist propaganda, supply and demand. It is important to create evaluation criteria which should be determined and consistent, both in qualitative and quantitative terms, as an attempt towards solving the existing problems in the rural tourism development. Tourist agencies must be engaged in enabling a dialogue between their employees and local representatives. Clients must not only be observers 
but also critics in the spirit of trust and transparency. A full and true comprehension of the rural tourism role is realized through revealing habits of the host, traditional values rooted in the existing culture, establishment of relations amongst population at the local level.

Rural tourism in Serbia must be a move towards the revitalization of the village and its inhabitants. In Serbia, a revitalization of the village has become an issue of crucial importance. It is quite clear, that the rural tourism development can give contribution to the village revitalization. This is obvious from the previous experience.

\section{Bibliography}

Amirou, R 200o, Le tourisme local, p.137-149, Paris.

National Tourism Organization of Serbia, Categorization by Tourist Organization of Serbia, viewed on August 2011, http://www.serbia.travel/destinations/villages/.

Corrigan, P 1997, The Sociologi of Consumption, p.39, London.

Cvetković , M 2007, The Guide of Tourist Manifestations, IPG International, p.7-42, Belgrade.
Dan,G \& Cohen, E 1991, Sociology of tourism, p.45-6o, New York.

Darnil, S \& Le Roux, M 2005,80 Homemes pour changer le Mond, 282.p, Paris.

Damazedier, J 1962, Vers une civilisation du loisir, 320.p, Paris.

Group of Authors 1983, 'Blessed are the ways of Yugoslavia', Publik Yugoslavia, p.21-30, Belgrade.

Group of Authors 2009, 'Upoznajte Srbiju 2, Salasi Vojvodine', Politika, p.4-22, Belgrade.

Group of Authors 2009, 'Edition'Upoznajte Srbiju 1, Etno sela Srbije', Politika, Belgrade,

p.4-22.

Guido Van, H, Isabel, V, Mieke, C \& Liesbeth, V 2006, 'Synergies between Farming and Rural Tourism: Evidence from Flanders', EuroChoices, vol. 5, issue 1, p.14-21.

Hopic, S 2010, 'Rural Development in the Republic of Serbia', Project EXCHANGE 2, financed by EU, Publisher, Standing Conference of Cities and Municipalities, p. 9-11, Belgrade.

Master plan of the Republic of Serbia for the rural development, viewed on May 2011, http://www.selo.rs/Master-plan-razvoja-seoskog-turizmaSrbije_516.

Milosavljevic, S 2008, Vrnjacka banja-socio-geographical study (monograph), IK 'Ljubostinja', p.1-9o, Trstenik. 